\title{
Pectobacterium atrosepticum (van Hall) Gardan et al. as a Causal Agent of Potato Blackleg in Greenland
}

\author{
Eigil de Neergaard $\cdot$ Susanne Harding $\cdot$ Robert \\ Czajkowski (i)
}

Accepted: 19 April 2020 / Published online: 30 April 2020

(C) The Author(s) 2020

\begin{abstract}
As a part of a blackleg and soft rot survey on potato plants cultivated in the agricultural region of Southern Greenland during the growing season of 2019 diseased potato plants and tubers were collected at six localities. Samples of plants and tubers with typical blackleg and soft rot symptoms were cut into parts weighing ca. $10-15 \mathrm{~g}$ each and incubated in potato enrichment broth (PEB) under anaerobic conditions for 4-7 days at ca. $20-22{ }^{\circ} \mathrm{C}$ (conditions during shipment of the samples from Greenland to Poland). After enrichment plant extracts were plated on crystal violet pectate (CVP) medium to isolate individual cavity-forming bacterial colonies. The inoculated plates were incubated at 22, 25 and $28{ }^{\circ} \mathrm{C}$ to maximize the chance of finding pectinolytic bacteria with different growth temperature optima. Cavity-forming isolates were collected and purified to pure cultures on tryptone soya agar (TSA). Ten cavity-forming isolates, named Green 1 - Green10, representing isolates from symptomatic plants from different locations, were selected for analyses. The isolates gave a 434 bp. product in Pectobacterium spp.-specific PCR and a 439 bp. product in P. atrosepticum (Pba) -
\end{abstract}

E. de Neergaard $\cdot$ S. Harding

Plant Health in Greenland, Strandgade 39, DK-3000 Helsingør, Denmark

\section{R. Czajkowski ( $\bowtie)$}

Division of Biologically Active Compounds, Intercollegiate Faculty of Biotechnology, University of Gdansk and Medical University of Gdansk, Antoniego Abrahama 58, 80-307 Gdansk, Poland

e-mail: Robert.Czajkowski@biotech.ug.edu.pl specific PCR. These isolates were Gram (-) rods, facultative anaerobic, catalase positive, oxidase and indole negative, grew in $\mathrm{TSB}+5 \% \mathrm{NaCl}$, produced acid from lactose, maltose and raffinose. BlastN analyses of the ca. $1300 \mathrm{bp} .16 \mathrm{~S}$ rDNA sequences of all 10 strains indicated a $99-100 \%$ similarity to the $16 \mathrm{~S}$ rDNA of Pectobacterium atrosepticum. All 10 isolates caused soft rot of potato tuber slices after $72 \mathrm{~h}$ at $28{ }^{\circ} \mathrm{C}$. Phylogenetic analysis based on the recA gene sequence grouped the isolates together with $P$. atrosepticum strains CFBP1526T and SCRI1043. This is the first report on isolation of $P$. atrosepticum from blacklegdiseased potato plants in Greenland. The presence of $P$. atrosepticum and its possible impact on potato cultivation in Greenland is discussed.

Keywords Erwinia atroseptica Solanum tuberosum . Wilting $\cdot$ Soft rot $\cdot$ Chlorosis $\cdot$ Climate change

Potato (Solanum tuberosum L.) is a worldwide cultivated tuberous plant and the fourth main food crop in the world after rice, maize and wheat both when counting area used for crop cultivation and its total production (Bishop et al. 2012; Bradshaw and Ramsay 2009, FAOSTAT 2020 (http://www.fao.org)). The area of potato cultivation is rapidly increasing especially in developing regions. This is due to the fact that commercial potato cultivars may be selected to grow under a broad range of soil and temperature conditions. Likewise, potato has been for a long time a major field crop in temperate and progressively also in warmer 
European regions (Czajkowski et al. 2011, Pawelzik and Möller 2014).

With the increasing temperatures due to climate change, the agricultural production in subarctic and boreal regions in Greenland is expected to expand in the near future (Barbeau et al. 2015; Lehmann et al. 2016; Munk et al. 2009). In Greenland, potato tubers are produced mainly within the agricultural area in the southwestern part of the island, mainly along the fjords on the west coast between $60{ }^{\circ} \mathrm{N}$ and $61.5^{\circ} \mathrm{N}$. Potato plants are cultivated on a commercial scale by a limited number of sheep holders. Furthermore, a small scale production of potato tubers for private consumption takes place at many locations in Greenland (de Neergaard and Harding 2020).

In Greenland, no production of certified seed potato tubers takes place. Seed potato tubers are imported from the European Union, primarily from Denmark, Norway and the Netherlands (de Neergaard, personal communication). Alternatively, home-saved potatoes are used as a planting material in the following season (Munk et al. 2009). Likewise, potatoes for consumption imported from outside Europe (e.g. Egypt) and sold in local supermarkets are occasionally used as seed material. Planting of potato tubers takes place between late May and mid-June, and the crop is harvested from midAugust to September. Due to steadily decreasing rainfall, reported during the recent decades, irrigation is frequently applied throughout the entire growing season (potato growers, personal communication). It is worth noting that Greenlandic potato production is carried out without the use of pesticides and that crop rotation is not practiced at the majority of potato production sites (potato growers, personal communication).

The majority of potato diseases present in Europe and worldwide (excluding late blight) has been already reported in Greenland (de Neergaard et al. 2014; de Neergaard and Harding 2020). In years with humid weather conditions suitable for pathogen spread, potato diseases develop often as vigorously as in the other parts of continental Europe (de Neergaard and Harding 2020). This is somehow remarkable since agriculture in Greenland is characterized by: (i) isolated cultivation sites often situated far from each other, (ii) very cold winter season, (iii) a very low number or absence of alternative hosts, as well as (iv) the absence of volunteers to transmit the pathogens to the following season.

In surveys undertaken in the period of 2007-2010 plants with symptoms of blackleg and soft rot were recorded in 11 out of 15 commercial potato fields screened (de Neergaard and Harding 2020). Blackleg and soft rot field assessments done in 2009 resulted in the incidence (measured as a percentage of symptomatic plants present) values of 2 to $7 \%$ (Munk and de Neergaard, personal observations). The accepted limit of disease incidence in seed potato tubers in Europe differs per tuber class and the respective EU member state regulations (Toth et al. 2011) but, in general, the incidence in certified seed tubers used as a planting material should remain zero or (in some cases) as low as possible. In Denmark the upper accepted limit of soft rot in certified seed potato tubers is $0.2 \%$ (Ministry of

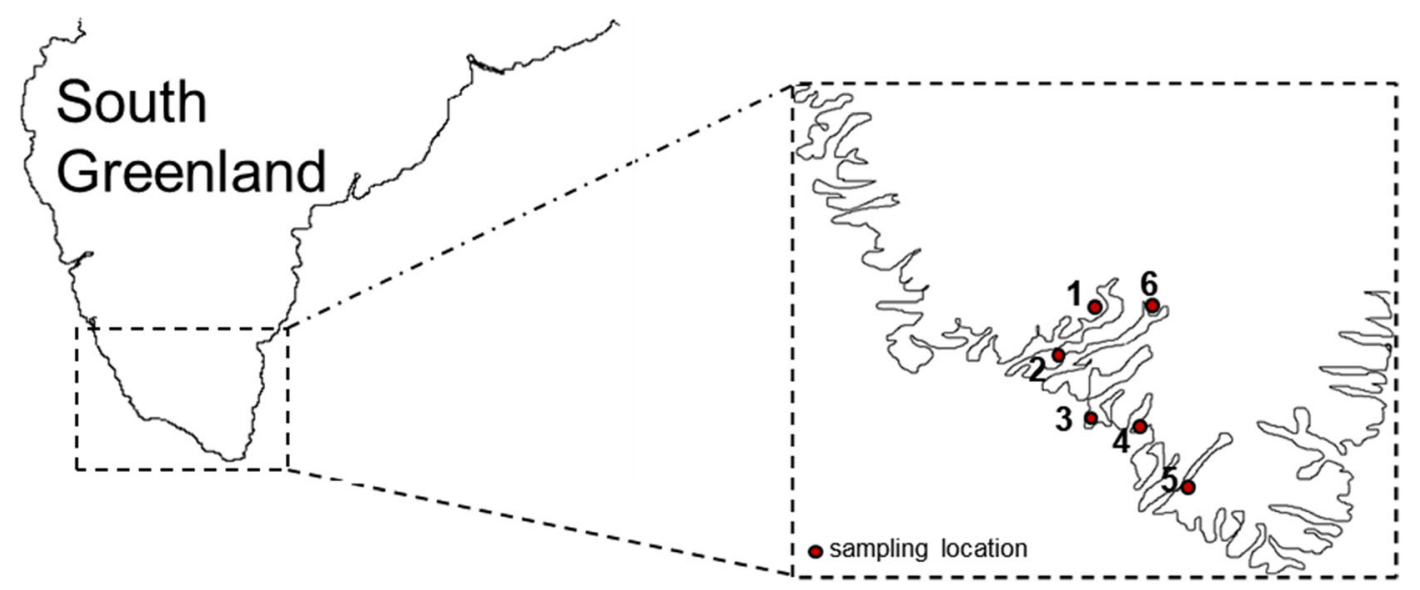

Fig. 1 Locations of potato fields in South Greenland from where diseased potato samples were obtained. 1: Eqaluit Ilua Sermilik, $61^{\circ} 07^{\prime} \mathrm{N}, 45^{\circ} 58^{\prime} \mathrm{W}, 2$ : Sarlia, Alanngorsup Nunaa, $60^{\circ} 50^{\prime} \mathrm{N}$, $46^{\circ} 08^{\prime}$ W, 3: Qaqortoq, $60^{\circ} 43^{\prime} \mathrm{N}, 46^{\circ} 02^{\prime} \mathrm{W}, 4$ : Ammassivik $60^{\circ}$ $36^{\prime} \mathrm{N}, 45^{\circ} 23^{\prime} \mathrm{W}, \mathbf{5}$ : Saputit Tasia,60 $14^{\prime} \mathrm{N}, 44^{\circ} 45^{\prime} \mathrm{W} \mathbf{6}$ : Narsarsuaq, $61^{\circ} 10^{\prime} \mathrm{N}, 45^{\circ} 26^{\prime} \mathrm{W}$. No $P$. atroseptica isolates were found in samples collected from symptomatic plants at Saputit Tasia 
Fig. 2 Blackleg and soft rot symptoms on potato tubers. Representative, symptomatic plants before sampling (field grown) (A) and collected for analyses (B) are shown. Typical symptoms including: wilting and chlorosis/discoloration of leaves (1), blackleg lesions on stems (2), rotting of seed (mother) tuber (3) are marked with arrows (B)

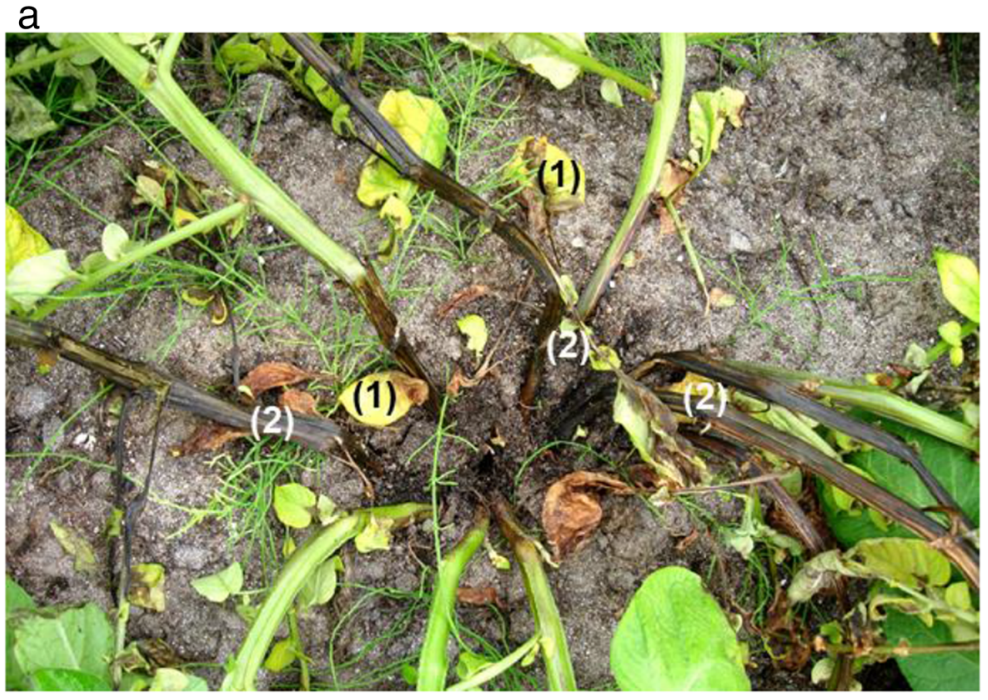

b

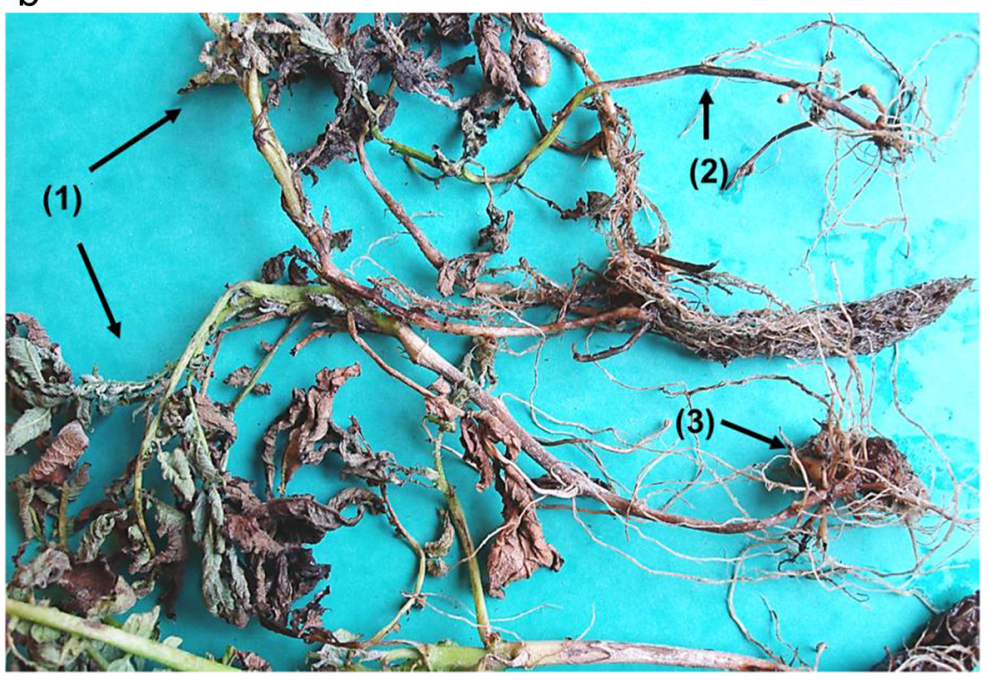

Environment and Food 2020: Bekendtgørelse om avl mv. af kartofler. BEK $\mathrm{Nr} 81$, https://www. retsinformation.dk/eli/lta/2020/81).

A follow-up survey for potato blackleg and soft rot was undertaken in the potato production region in South Greenland from August to September 2019. All commercial potato growers (six) were included in the survey. Furthermore, the plants from potato cultivar trials at the Agricultural Experiment Station in Upernaviarsuk together with the plants in 12 smallholder sites with potato cultivation were evaluated for the presence of blackleg and soft rot. At six localities (Fig. 1) symptoms including blackleg, chlorosis, wilting, stem rot, preemergence tuber rot and soft rot of (seed and progeny) tubers in field-growing potato plants were observed (Fig. 2). These symptoms resembled typical potato blackleg symptoms caused by soft rot Pectobacteriaceae (SRP: Pectobacterium spp. and Dickeya spp.) previously described on potatoes in Europe and worldwide (Pérombelon 2002; Charkowski 2007).

Stem parts with typical blackleg symptoms and potato tubers expressing soft rot were collected and transported to the field laboratory in Greenland. Samples were incubated in potato enrichment broth (PEB) medium (Pérombelon and van der Wolf 2002) in $50 \mathrm{ml}$ Falcon tubes for $4-7$ days at $20-22{ }^{\circ} \mathrm{C}$ to increase the size of SRP bacterial populations. The tubes were tightly 
Table 1 Bacterial isolates characterized in this study

\begin{tabular}{|c|c|c|c|c|c|}
\hline No. & $\begin{array}{l}\text { Isolate } \\
\text { name }\end{array}$ & Location & $\begin{array}{l}\text { Potato } \\
\text { cultivar }\end{array}$ & Cultivation history & $\begin{array}{l}\text { Bacterial species } \\
\text { present }\end{array}$ \\
\hline 1 & Green 1 & $\begin{array}{l}\text { Qaqortoq, } \\
\left(60^{\circ} 43^{\prime} \mathrm{N}, 46^{\circ} 02^{\prime} \mathrm{W}\right)\end{array}$ & unknown & continuous potato cultivation, soil $\mathrm{pH} 4.5$ & $\begin{array}{r}\text { Pectobacterium } \\
\text { atrosepticum }\end{array}$ \\
\hline 2 & Green2 & $\begin{array}{l}\text { Qaqortoq, } \\
\left(60^{\circ} 43^{\prime} \mathrm{N}, 46^{\circ} 02^{\prime} \mathrm{W}\right)\end{array}$ & unknown & continuous potato cultivation, soil pH 4.5 & P. atrosepticum \\
\hline 3 & Green3 & $\begin{array}{l}\text { Ammassivik, } \\
\left(60^{\circ} 36^{\prime} \mathrm{N}, 45^{\circ} 23^{\prime} \mathrm{W}\right)\end{array}$ & Folva & continuous potato cultivation, soil $\mathrm{pH} 4.0$ & P. atrosepticum \\
\hline 4 & Green4 & $\begin{array}{l}\text { Ammassivik, } \\
\left(60^{\circ} 36^{\prime} \mathrm{N}, 45^{\circ} 23^{\prime} \mathrm{W}\right)\end{array}$ & Folva & continuous potato cultivation, soil $\mathrm{pH} 4.0$ & P. atrosepticum \\
\hline 5 & Green5 & $\begin{array}{l}\text { Eqaluit Ilua, Sermilik, } \\
\left(61^{\circ} 07^{\prime} \mathrm{N}, 45^{\circ} 58^{\prime} \mathrm{W}\right)\end{array}$ & Folva & crop rotation, soil $\mathrm{pH} 5.0$ & P. atrosepticum \\
\hline 6 & Green6 & $\begin{array}{l}\text { Sarlia, Alanngorsup } \\
\text { Nunaa } \\
\left(60^{\circ} 50^{\prime} \mathrm{N}, 46^{\circ} 08^{\prime} \mathrm{W}\right)\end{array}$ & Folva & $\begin{array}{l}\text { potato cultivation for the first time on this location, } \\
\text { soil } \mathrm{pH} 4.0\end{array}$ & P. atrosepticum \\
\hline 7 & Green 7 & $\begin{array}{l}\text { Sarlia, Alanngorsup } \\
\text { Nunaa } \\
\left(60^{\circ} 50^{\prime} \mathrm{N}, 46^{\circ} 08^{\prime} \mathrm{W}\right)\end{array}$ & Folva & $\begin{array}{l}\text { potato cultivation for the first time on this location, } \\
\text { soil } \mathrm{pH} 4.0\end{array}$ & P. atrosepticum \\
\hline 8 & Green8 & $\begin{array}{l}\text { Qaqortoq, } \\
\left(60^{\circ} 43^{\prime} \mathrm{N}, 46^{\circ} 02^{\prime} \mathrm{W}\right)\end{array}$ & unknown & continuous potato cultivation, soil $\mathrm{pH} 4.5$ & P. atrosepticum \\
\hline 9 & Green9 & $\begin{array}{l}\text { Narsarsuaq, } \\
\left(61^{\circ} 10^{\prime} \mathrm{N}, 45^{\circ} 26^{\prime} \mathrm{W}\right)\end{array}$ & Asparges & continuous potato cultivation, soil $\mathrm{pH} 5.5$ & P. atrosepticum \\
\hline 10 & Green 10 & $\begin{array}{l}\text { Narsarsuaq, } \\
\left(61^{\circ} 10^{\prime} \mathrm{N}, 45^{\circ} 26^{\prime} \mathrm{W}\right)\end{array}$ & Asparges & continuous potato cultivation, soil $\mathrm{pH} 5.5$ & P. atrosepticum \\
\hline
\end{tabular}

closed to provide low oxygen conditions during incubation. The enriched samples were used for isolation of SRP. In the laboratory in Poland, $100 \mu$ of each of the enriched samples was serially diluted and separately plated on crystal violet pectate (CVP) (Hélias et al. 2011) plates and incubated at 22,25 and $28{ }^{\circ} \mathrm{C}$ for up to 5 days. Three different incubation temperatures were chosen to maximize the chances of finding SRP with different growth temperature optima (du Raan et al. 2016). Pectinolytic bacterial isolates producing typical cavities (pits) on CVP plates were collected and purified to pure cultures on tryptone soya agar (TSA) as previously described by Czajkowski et al. (2015). Ten cavityforming isolates, named Green 1 - Green10 (Table 1) and representing isolates collected from symptomatic plants at different locations, were selected for further analysis.

Gram staining of the isolates was done as described by Coico (2006). Biochemical assays, including growth at $37^{\circ} \mathrm{C}$, growth in tryptone soya broth (TSB) supplemented with $5 \% \mathrm{NaCl}$, growth under anaerobic conditions, activity of catalase and oxidase, production of indole, production of acid from lactose, maltose and raffinose were done as described by Pérombelon and van der Wolf (2002) and Czajkowski et al. (2009). The
Green1 - Green10 isolates were Gram(-) rods, facultative anaerobic, catalase positive, oxidase and indole negative, did not grow at $37^{\circ} \mathrm{C}$ but grew in TSB $+5 \%$ $\mathrm{NaCl}$ and under anaerobic conditions and produced acid from lactose, maltose and raffinose. These tests allowed classifying the Green 1-Green 10 isolates to $P$. atrosepticum species.

For molecular characterization of pectinolytic bacterial isolates a colony PCR procedure was used as described in Czajkowski et al. (2009). PCR detection of Dickeya spp. was performed according to Nassar et al. (1996) using ADE1/ADE2 primers (ADE1: 5'GATCAGAAAGCCCGCAGCCAGAT 3', ADE2: 5'CTGTGGCCGATCAGGATGGTTTTGTCGTGC $\left.3^{\prime}\right)$. Detection of Pectobacterium spp. was performed according to Darrasse et al. (1994) using Y1/Y2 primers (Y1: 5'TTACCGGACGCCGAGCTGTGGCGT 3 ', Y2: 5'CAGGAAGATGTCGTTATCGCGAGT '3). PCR detection of $P$. atrosepticum was performed according to Frechon et al. (1998) using Y45/Y46 (Y45: 5'TCACCGGACGCCGAACTGTGGCGT 3', Y46: 5'TCGCCAACGTTCAGCAGAACAAGT 3') primers. In all cases, amplified DNA was detected by electrophoresis in a $1.5 \%$ agarose gel in $0.5 \times \mathrm{TBE}$ buffer and stained with $5 \mathrm{mg} \mathrm{ml}^{-1}$ of GelRed (Biotium). The 


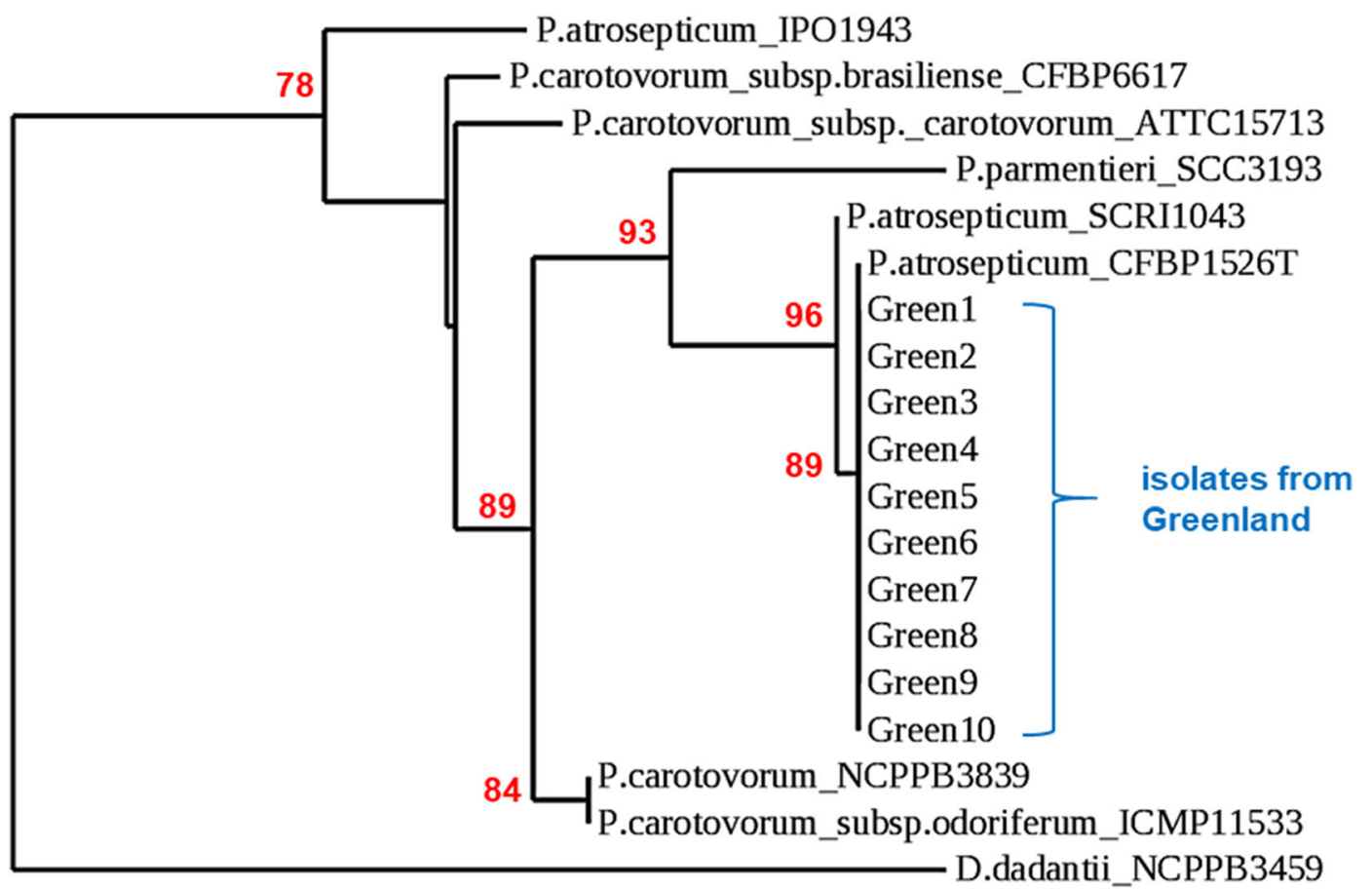

\section{1}

Fig. 3 Maximum likelihood (ML) phylogenetic tree based on the aligned recA gene sequences of Green1-Green10 isolates. Phylogenetic studies were performed using Phylogenetic Pipeline of Information Génomique et Structurale, CNRS-AMU, France (http://www.phylogeny.fr/) with bootstrap support for 1000 replicates. The bar indicates the number of substitutions per sequence position. The cutoff for separating the clades was the bootstrap support for particular branch (n) of at least $70 \%$ together with the bootstrap support for particular predecessor branch (n-1)

Green1 - Green10 bacterial isolates, gave a 434 bp. product in Pectobacterium spp.-specific PCR and a 439 bp. product in P. atrosepticum (Pba) -specific PCR but no product was detected after a PCR with ADE1/ ADE2 primers. The results of the PCR assays indicated that all 10 isolates belonged to P. atrosepticum.

The genomes of Green $1-$ Green 10 were sequenced at the Institute of Biochemistry and Biophysics, Polish Academy of Science, Warsaw, Poland and annotated using RAST (Aziz et al. 2008). Identification of Green1 - Green 10 isolates by $16 \mathrm{~S}$ rDNA sequence analysis was done according to Czajkowski et al. (2012). NCBI BlastN analyses of the ca. 1200-1300 bp. 16S rDNA sequences of Green 1 - Green10 strains (Genbank accession no.: MT318667-MT318676) derived from the bacterial genomes indicated a $99-100 \%$ similarity to the $16 \mathrm{~S}$ rDNA of $P$. atrosepticum. Multiple sequence of at least $70 \%$. recA gene sequences of $P$. atrosepticum strain IPO1943, SCRI1043 and CFBP1526T, P. carotovorum Subs $p$. brasiliense CFBP6617, P. carotovorum subsp. carotovorum strain ATTC15713, P. parmentieri strain SCC3193, P. carotovorum strain NCPPB3839, P. carotovorum subsp. odoriferum strain ICMP11533 and $D$. dadantii strain NCPPB3459 were all retrieved from NCBI Genbank (https://www.ncbi.nlm.nih.gov/genbank/). The recA gene sequence from $D$. dadantii NCBBP3459 was used as an outgroup

alignment of recA gene and phylogenetic analyses were performed using Phylogenetic Pipeline of Information Génomique et Structurale, CNRS-AMU, France (http://www.phylogeny.fr/) as described in Czajkowski (2019). The phylogenetic analysis grouped the Green 1 Green 10 isolates together with $P$. atrosepticum strains CFBP1526T and SCRI1043 (Fig. 3).

None of the pectinolytic isolates characterized in this study was classified as Dickeya spp., which may suggest that these bacteria have not yet been introduced to Greenland and/or that the environmental conditions in agricultural fields there (low temperatures during and between growing seasons, low precipitation) do not support buildup of Dickeya spp. populations (Toth et al. 2011). For a long time, Dickeya spp. have been associated with blackleg in tropical and subtropical regions only (Pérombelon 2002), however the so-called 
cold tolerant strains of $D$. dianthicola were occasionally found in potato in Western and Northern Europe including Denmark in the last four decades (Janse and Ruissen 1988). Indeed, $D$. dianthicola is now commonly reported in Danish seed potato fields (Nielsen et al. 2011). Since 2000, a new aggressive species of Dickeya named D. solani has spread in Europe (van der Wolf et al. 2014) including countries with temperate climate: Poland, Sweden, Denmark, the Netherlands and Finland, and the new species seems to replace (competitively) $D$. dianthicola in potato in Danish agricultural fields (cabi.org/isc/datasheet/120278). At the moment $D$. solani remains one of the major threats to potato cultivation in many locations in Europe (van der Wolf et al. 2014). In Denmark, both $D$. dianthicola and $D$. solani have been frequently reported and the isolation of bacteria from the same locations supports the theory that two or three different SRP species may co-occur in the same plant (Nielsen et al. 2011).

Likewise, this survey has not resulted in the isolation of the emerging SRP pathogens currently limiting potato production under European climatic conditions (van der Wolf et al. 2017) viz. P. parmentieri and P. brasiliense. It can be assumed that these pathogens have not yet been transferred to Greenland with seed potato tubers originating in Europe and/or that, similarly, as in case of Dickeya spp., they require higher temperatures during the growing season to survive and cause symptoms in developing potato plants (van der Wolf et al. 2017).

In conclusion, this is the first report demonstrating the presence of the pectinolytic blackleg pathogen $P$. atrosepticum in potato cultivation in Greenland. Observations made during the growing season and isolation of the bacteria from symptomatic plants and tubers at different locations indicate that the pathogen may be widespread in Greenland. Blackleg and/or soft rot outbreaks in potato may become more severe in the coming years, especially if the climate becomes more suitable for pathogens belonging to Pectobacteriaceae (Skelsey et al. 2018). Furthermore, as disease symptoms were frequently observed at production localities where no crop rotation was practiced, the role of pathogen survival in soil should be more deeply investigated (Pérombelon 2002). Precautions, including efficient pathogen detection in potato seed tubers before planting, rotation of crops to decrease the survival of $P$. atrosepticum in field soils, monitoring of surface water for the presence of SRP and compulsory use of certified seed potato tubers should be considered.

Acknowledgements The work was financially supported by Den Grønlandske Fond, Greenland, Denmark grant no. 2018-02-070 / RIGS-GL 2018-542 to Eigil de Neergaard and by the University of Gdansk, Poland (Uniwersytet Gdański, Polska) grant no. 531-N104D800-20 to Robert Czajkowski. Non-financial support including transport and other support has been received from the Agricultural Consulting Services in Greenland. The authors are grateful to Hans Hansen, Aqqalooraq Frederiksen, Efa Poulsen, and Augusta Egede, as well as to all potato growers visited for their hospitality and for providing information valuable for this study.

Compliance with ethical standards The results presented in this manuscript did not involve any protected and/or endangered species, human participants, specimens or tissue samples, or vertebrate animals, embryos or tissues.

Conflict of interest The authors declare that no conflict of interest exists.

Informed consent All authors consent to this submission.

Open Access This article is licensed under a Creative Commons Attribution 4.0 International License, which permits use, sharing, adaptation, distribution and reproduction in any medium or format, as long as you give appropriate credit to the original author(s) and the source, provide a link to the Creative Commons licence, and indicate if changes were made. The images or other third party material in this article are included in the article's Creative Commons licence, unless indicated otherwise in a credit line to the material. If material is not included in the article's Creative Commons licence and your intended use is not permitted by statutory regulation or exceeds the permitted use, you will need to obtain permission directly from the copyright holder. To view a copy of this licence, visit http://creativecommons.org/licenses/by/4.0/.

\section{References}

Aziz, R. K., Bartels, D., Best, A. A., DeJongh, M., Disz, T., Edwards, R. A., Formsma, K., Gerdes, S., Glass, E. M., Kubal, M., Meyer, F., Olsen, G. J., Olson, R., Osterman, A. L., Overbeek, R. A., McNeil, L. K., Paarmann, D., Paczian, T., Parrello, B., Pusch, G. D., Reich, C., Stevens, R., Vassieva, O., Vonstein, V., Wilke, A., \& Zagnitko, O. (2008). The RAST server: Rapid annotations using subsystems technology. BMC Genomics, 9, 75-75.

Barbeau, C. D., Oelbermann, M., Karagatzides, J. D., \& Tsuji, L. J. S. (2015). Sustainable agriculture and climate change: Producing potatoes (Solanum tuberosum L.) and bush beans (Phaseolus vulgaris L.) for improved food security and resilience in a Canadian subarctic first nations community. Sustainability, 7, 5664-5681. 
Bishop, C., Rees, D., Cheema, M. U. A., Harper, G., \& Stroud, G. (2012). Potatoes. In Crop Post-Harvest: Science and Technology (pp. 334-359): Wiley-Blackwell, USA.

Bradshaw, J. E., \& Ramsay, G. (2009). Potato origin and production. In Advances in potato chemistry and technology (pp. 126): Elsevier, USA.

Charkowski, A. O. (2007). The soft rot Erwinia. Plant-Associated Bacteria, part, 3, 423-505.

Coico, R. (2006). Gram staining. Current Protocols in Microbiology, 00(1), a.3C.1-a.3C.2, doi:https://doi. org/10.1002/9780471729259.mca03cs00.

Czajkowski, R. (2019). May the phage be with you? Prophage-like elements in the genomes of soft rot Pectobacteriaceae: Pectobacterium spp. and Dickeya spp. Frontiers in Microbiology, 10, fmicb.2019.00138.

Czajkowski, R., de Boer, W. J., van Veen, J. A., \& van der Wolf, J. M. (2012). Characterization of bacterial isolates from rotting potato tuber tissue showing antagonism to Dickeya sp. biovar 3 in vitro and in planta. Plant Pathology, 61, 169-182.

Czajkowski, R., Grabe, G. J., \& van der Wolf, J. M. (2009). Distribution of Dickeya spp. and Pectobacterium carotovorum subsp. carotovorum in naturally infected seed potatoes. European Journal of Plant Pathology, 125, 263-275.

Czajkowski, R., Pérombelon, M. C. M., Jafra, S., Lojkowska, E., Potrykus, M., van der Wolf, J. M., et al. (2015). Detection, identification and differentiation of Pectobacterium and Dickeya species causing potato blackleg and tuber soft rot: A review. Annals of Applied Biology, 161, 18-38.

Czajkowski, R., Pérombelon, M. C. M., van Veen, J. A., \& van der Wolf, J. M. (2011). Control of blackleg and tuber soft rot of potato caused by Pectobacterium and Dickeya species: A review. Plant Pathology, 60, 999-1013.

Darrasse, A., Priou, S., Kotoujansky, A., \& Bertheau, Y. (1994). PCR and restriction fragment length polymorphism of a pel gene as a tool to identify Erwinia carotovora in relation to potato diseases. Applied and Environmental Microbiology, 60, 1437-1443.

Frechon, D., Exbrayat, P., Helias, V., Hyman, L. J., Jouan, B., Llop, P., Lopez, M. M., Payet, N., Pérombelon, M. C. M., Toth, I. K., van Beckhoven, J. R. C. M., van der Wolf, J. M., \& Bertheau, Y. (1998). Evaluation of a PCR kit for the detection of Erwinia carotovora subsp. atroseptica on potato tubers. Potato Research, 41, 163-117.

Hélias, V., Hamon, P., Huchet, E., Wolf, J. V. D., \& Andrivon, D. (2011). Two new effective semiselective crystal violet pectate media for isolation of Pectobacterium and Dickeya. Plant Pathology, 61, 339-345.

Janse, J. D., \& Ruissen, M. A. (1988). Characterization and classification of Erwinia chrysanthemi strains from several hosts in the Netherlands. Phytopathology 78, 800-808.

Lehmann, J. O., Sharif, B., Kjeldsen, C., Plauborg, F., Olesen, J. E., Mikkelsen, M. H., et al. (2016). Muligheder for klimatilpasning i landbrugserhvervet-status og handlemuligheder. Tjele: Aarhus Universitet, Institut for Agroøkologi/Naalakkersuisut: The Government of Greenland.

Munk, L., de Neergaard, E., Stougaard, P., \& Høegh, K. (2009). Climatic changes and agriculture in Greenland: Plant diseases in potatoes and grass fields IARU Climate Conference, Copenhagen, Denmark.
Nassar, A., Darrasse, A., Lemattre, M., Kotoujansky, A., Dervin, C., Vedel, R., \& Bertheau, Y. (1996). Characterization of Erwinia chrysanthemi by pectinolytic isozyme polymorphism and restriction fragment length polymorphism analysis of PCR- amplified fragments of pel genes. Applied and Environmental Microbiology, 62, 2228-2235.

de Neergaard, E., \& Harding, S. (2020). Plant pests and diseases in agricultural areas in southern Greenland. Background report / review. Greenland Agricultural Research Network / Greenland Agriculture Initiative (GRAIN) Ilisimatusarfik (University of Greenland), (in press).

de Neergaard, E., Munk, L., \& Nielsen, S. L. (2014). First report of potato leafroll virus, potato virus a, potato virus $\mathrm{X}$ and potato virus Y in potato in Greenland. New Disease Reports, 30, 20.

Nielsen, L. S., Tøndersen, T., \& Bødker, L. (2011). Typer af sortbensyge / blødrådbakterier (Erwinia-komplekset) i Danmark. Plantekongres 2011, Aarhus Universitet, Aarhus, Denmark.

Pawelzik, E., \& Möller, K. (2014). Sustainable potato production worldwide: The challenge to assess conventional and organic production systems. Potato Research, 57, 273-290.

Pérombelon, M. C. M. (2002). Potato diseases caused by soft rot Erwinias: An overview of pathogenesis. Plant Pathology, 51, $1-12$.

Pérombelon, M. C. M., \& van der Wolf, J. M. (2002). Methods for the detection and quantification of Erwinia carotovora subsp. atroseptica (Pectobacterium carotovorum subsp. atrosepticum) on potatoes: A laboratory manual. Scottish crop research institute annual report, 10, Dunde, Scotland, UK.

du Raan, S., Coutinho, T. A., \& van der Waals, J. E. (2016). Cardinal temperature differences, determined in vitro, between closely related species and subspecies of pectinolytic bacteria responsible for blackleg and soft rot on potatoes. European Journal of Plant Pathology, 144, 361-369.

Skelsey, P., Humphris, S. N., Campbell, E. J., \& Toth, I. K. (2018). Threat of establishment of non- indigenous potato blackleg and tuber soft rot pathogens in Great Britain under climate change. PLoS ONE, 13, e0205711.

Toth, I. K., van der Wolf, J. M., Saddler, G., Lojkowska, E., Hélias, V., Pirhonen, M., Tsror Lahkim, L., \& Elphinstone, J. G. (2011). Dickeya species: An emerging problem for potato production in Europe. Plant Pathology, 60, 385-399.

van der Wolf, J. M., de Haan, E. G., Kastelein, P., Krijger, M., de Haas, B. H., Velvis, H., Mendes, O., Kooman-Gersmann, M., \& van der Zouwen, P. S. (2017). Virulence of Pectobacterium carotovorum subsp. brasiliense on potato compared with that of other Pectobacterium and Dickeya species under climatic conditions prevailing in the Netherlands. Plant Pathology, 66, 571-583.

van der Wolf, J. M., Nijhuis, E. H., Kowalewska, M. J., Saddler, G. S., Parkinson, N., Elphinstone, J. G., Pritchard, L., Toth, I. K., Lojkowska, E., Potrykus, M., Waleron, M., de Vos, P., Cleenwerck, I., Pirhonen, M., Garlant, L., Helias, V., Pothier, J. F., Pfluger, V., Duffy, B., Tsror, L., \& Manulis, S. (2014). Dickeya solani sp. nov., a pectinolytic plant pathogenic bacterium isolated from potato (Solanum tuberosum). International Journal of Systematic and Evolutionary Microbiology, 64, 768-774. 